\title{
EDITORIAL
}

\section{Farewell and hail}

\author{
Harold Merskey DM FRCP FRCPC FRCPsych
}

W th this issue, I will have completed 12 years as the founding Editor-in-Chief of Pain Research $\mathscr{E}$ Management, and will have seen 10 years of its publication. The work has rarely been a burden; the two most consistently rewarding features have been my personal interest in the content and the repeated expressions of satisfaction by members of the Canadian Pain Society and other friends. This is not the occasion to evaluate the success of the Journal, nor should I be the person to do so, but it is the occasion for me to thank those who induced me to take on the position of Editor-in-Chief of Pain Research $\mathcal{E}$ Management and supported my efforts. They include John Weller, who initially worked for Pulsus Group, Pulsus Group Publisher Bob Kalina and Vice-President Ann LeBlanc, as well as the Executive of the Canadian Pain Society. All of them have been unfailingly helpful and supportive. The Publisher's commitment to developing Canadian medical journals has been a blessing to the Canadian Pain Society, and I presume to other societies as well.

I can claim much experience from an author's point of view as a result of dealing with the staff of other medical journals and publishers. Without any doubt, the copy editing provided by
Pulsus Group and the production by the managing editors have been superb, as good as any, and better than most of the journals with which I have been acquainted as an author or as a member of editorial boards. Likewise, the backing from the Executive and members of the society for the journal has been unfailing.

I am handing editorial charge of the Journal to Dr Kenneth Craig who will become Editor-in-Chief effective January 2006. Ken has been very successful as Editor-in-Chief of a psychology journal as well as a Past-President of the Canadian Pain Society. I will continue to read and enjoy the Journal, but it is time that I say farewell to the office of editor and hail to future issues and the next Editor-in-Chief. I expect to finish some work next year as a guest editor on a special supplement, which expresses my continuing commitment to the Journal and indicates a little of the importance that I attach to the continued existence and activities of Pain Research $\mathcal{E}$ Management.

It is clear that I want to express my thanks and the best way I can do this is by saying that I was given a unique opportunity and appreciate the support received from all those mentioned and many others.

Correspondence: Dr Harold Merskey, 71 Logan Avenue, London, Ontario N5Y 2P9. Telephone 519-679-1045, fax 519-679-6849,

e-mail harold.merskey@sympatico.ca

NOTE FROM THE PUBLISHER

\section{Thank you Dr Merskey! Welcome Dr Craig!}

\author{
Robert Kalina, Publisher
}

W hen we compare the launch of Pain Research $\mathcal{E}$ Management to other Pulsus journals, it took a relatively long time to come to fruition. It was at least two years before the idea of launching a new journal in this therapeutic area developed into the first issue. What took no time at all, however, was the selection of the founding Editor-in-Chief - Dr Harold Merskey. He was an obvious and welcome choice by everyone involved and he moved quickly and with great enthusiasm to launch the new Journal.

It takes one skill set to launch a new journal and quite another to grow it into an established and credible publication. Dr Merskey has managed to do both - Pain Research $\mathbb{E}$ Management is now 10 years old and is considered to be a viable, credible venue for Canadian researchers and practitioners. He has done this by bringing together various disciplines to work toward the lofty goal of understanding and managing pain. Dr Merskey has given us 10 years at the helm of Pain Research 89 Management and we thank him profusely.

To honour his tremendous contribution, Pulsus has instituted the Dr Harold Merskey Award in his honour. This Award will be given annually to the first author of an original article published in Pain Research $\mathcal{E}$ Management, judged by the Editor-in-Chief and Associate Editors as having the greatest impact on research and management of pain. The prize is donated by the Pulsus Group and consists of a Canadian work of art and \$1,000.

In 2006, the Journal begins another journey with a new Editor-in-Chief, Dr Kenneth Craig of Vancouver. Dr Craig has been charged with working with us to take this Journal to the next level - increasing its quality, appeal and stature and perhaps even frequency. He is eminently qualified and has been acknowledged by his peers as their undisputed choice for this role. We agree entirely and look forward to working with him on our plans for the Journal, including the on-line review system that will be implemented in the new year.

At this important juncture in the history of Pain Research $\mathbb{E}$ Management, all of us at Pulsus would like to take this opportunity to say thank you to Dr Harold Merskey and welcome to Dr Kenneth Craig. 


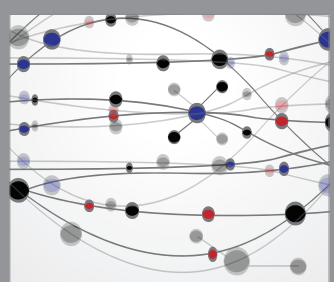

The Scientific World Journal
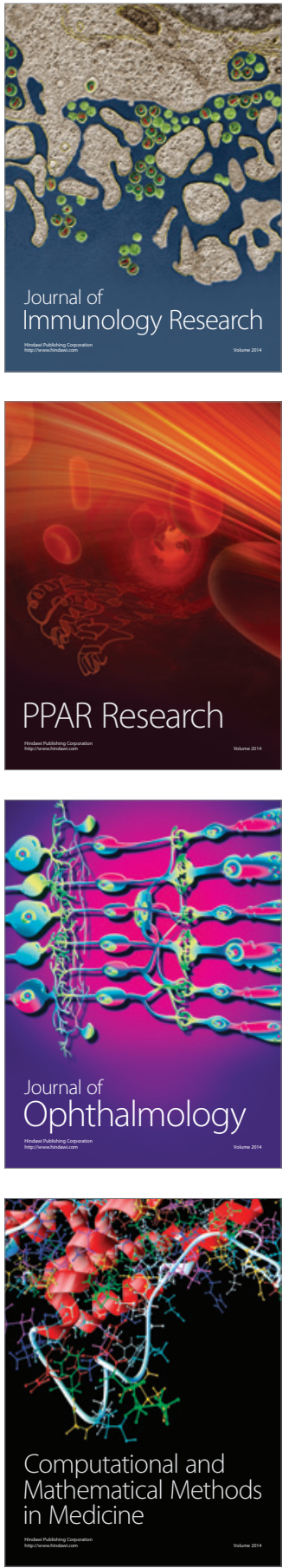

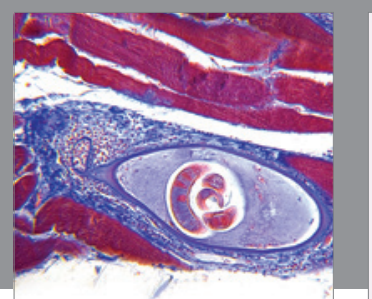

Gastroenterology Research and Practice

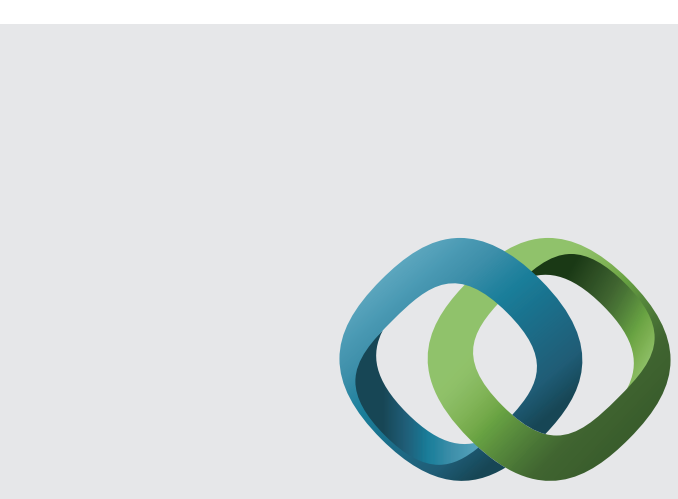

\section{Hindawi}

Submit your manuscripts at

http://www.hindawi.com
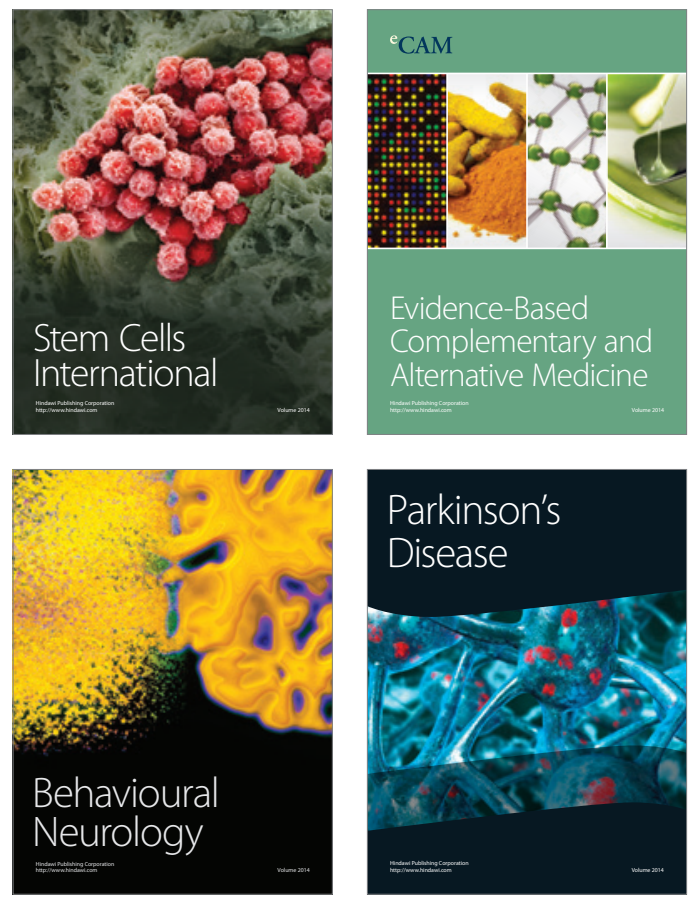
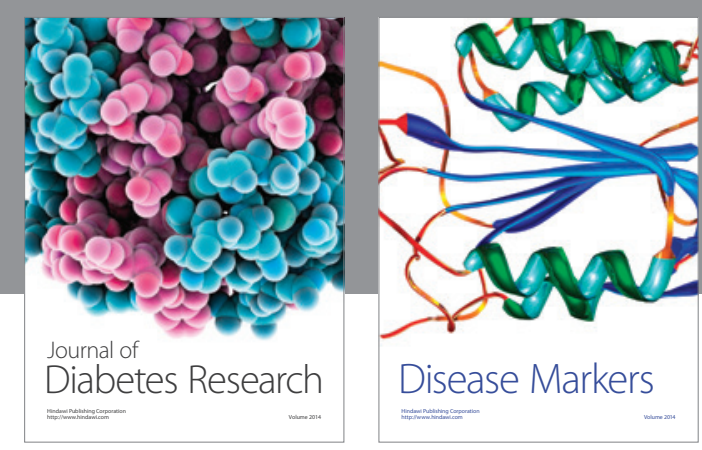

Disease Markers
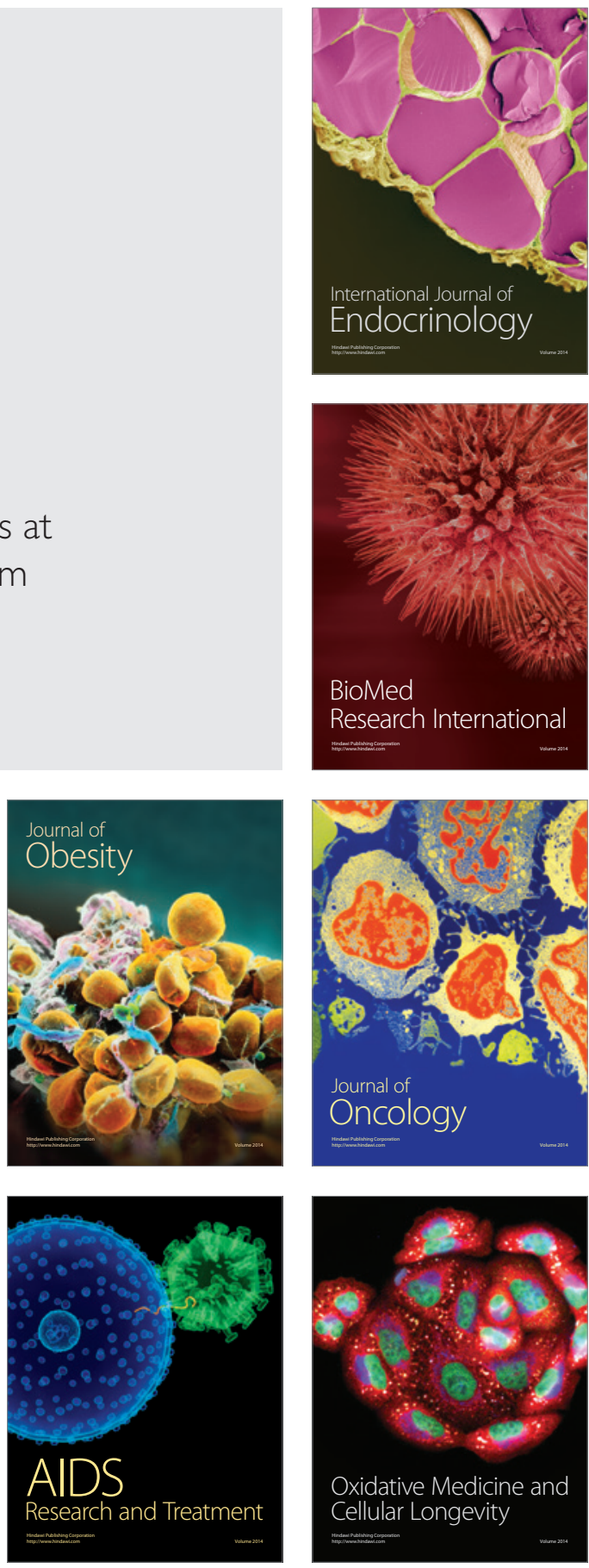